This item was submitted to Loughborough's Research Repository by the author.

Items in Figshare are protected by copyright, with all rights reserved, unless otherwise indicated.

\title{
The populism/anti-populism frontier and its mediation in crisis-ridden Greece: from discursive divide to emerging cleavage?
}

PLEASE CITE THE PUBLISHED VERSION

https://doi.org/10.1057/s41304-017-0138-3

\section{PUBLISHER}

Palgrave Macmillan (C) European Consortium for Political Research

\section{VERSION}

AM (Accepted Manuscript)

\section{PUBLISHER STATEMENT}

This work is made available according to the conditions of the Creative Commons Attribution-NonCommercialNoDerivatives 4.0 International (CC BY-NC-ND 4.0) licence. Full details of this licence are available at: https://creativecommons.org/licenses/by-nc-nd/4.0/

\section{LICENCE}

CC BY-NC-ND 4.0

\section{REPOSITORY RECORD}

Stavrakakis, Yannis, and Giorgos Katsampekis. 2019. "The Populism/anti-populism Frontier and Its Mediation in Crisis-ridden Greece: From Discursive Divide to Emerging Cleavage?”. figshare.

https://hdl.handle.net/2134/31992. 
The Populism/Anti-Populism Frontier and its Mediation in Crisis-Ridden Greece: from Discursive Divide to Emerging Cleavage?

\title{
Yannis Stavrakakis
}

Aristotle University of Thessaloniki, Political Sciences, 46 Egnatia, Thessaloniki, 54624, Greece

Email: yanstavr@yahoo.co.uk

\section{Giorgos Katsambekis}

Aristotle University of Thessaloniki, Political Sciences, 46 Egnatia, Thessaloniki, 54624, Greece

Email: giorgos_bek@hotmail.com

\begin{abstract}
Along with other South-European countries, since 2008, Greece has experienced deep economic and social dislocation, leading to a crisis of representation and triggering populist mobilisations and anti-populist reactions. This article focuses on the antagonistic language games developed around populist representations, something that has not attracted much attention in the relevant literature. Highlighting the need to study anti-populism together with populism, focusing on their mutual constitution from a discursive perspective, it articulates a brief yet comprehensive genealogy of populist and anti-populist actors (parties and media) in Greece, exploring their discursive strategies. Moving on, it identifies the main characteristics this antagonistic divide took on within the newly contested, crisis-ridden sociopolitical field, highlighting the implications for a contemporary understanding of cleavages, with potentially broader implications.
\end{abstract}

Keywords Populism · Anti-populism · Cleavage · Greece · Crisis · Mediation · SYRIZA 


\section{Introduction}

Along with other South-European countries, since 2008, Greece has experienced deep socio-economic dislocation, leading to a severe crisis of representation and, finally, triggering new populist mobilisations as well as anti-populist reactions. This, however, was not the first time the populism/anti-populism divide became a key factor in the Greek post-authoritarian context. It was rather the reactivation of a salient feature that has defined the Greek public sphere since the early 1980s, when the populist party PASOK established its long hegemony. Yet, while aspects of this antagonistic dialectic between populism and anti-populism have been occasionally discussed in the relevant literature (Lyrintzis, 2005; Pantazopoulos, 2011; Sevastakis and Stavrakakis, 2012), its real nature and implications have not been properly investigated.

Political scientists such as Nikiforos Diamandouros and Takis Pappas may have captured the importance of antagonism and polarisation - discussed by Diamandouros in terms of a pervasive 'dualism' - as well as the central role of populism in this division (Diamandouros, 1994; Pappas, 2014); however, over-identifying with a perspective premised on essentialised, euro-centric theories of modernisation and thus a priori accepting a one-sided, pejorative understanding of populism, they have failed to offer a truly reflexive theorisation of the populism/anti-populism frontier and of the role of both sides involved in constructing and reproducing it.

The present article is envisaged as responding to this gap in the literature. In order to do this, the 'important notion of anti-populism' which 'has never really been studied or thematized as such' (Ostiguy, 2009: 23-4) needs to be brought to the fore. Hence, highlighting the need to study populism and anti-populism together and focusing on their mutual constitution from a discursive perspective (Stavrakakis et al., 2017), we 
will articulate a brief yet comprehensive analysis of populist and anti-populist actors (parties and media) in contemporary Greece. In doing so, we reconstruct the development of the populist/anti-populist divide in Greece's post-authoritarian history, up until the recent crisis. Moving on, we identify the main characteristics (actors and strategies) this antagonistic divide took on within the newly contested, crisis-ridden public sphere. We conclude by drawing some implications for the broader area of populism research in Southern Europe and beyond.

\section{Conceptual Clarifications: Populism, Crisis, Mediation, Anti-Populism}

In line with an evolving consensus between discursive and ideational definitions (see Mudde and Kaltwasser 2017; Stavrakakis and Katsambekis, 2014), we understand populism as a specific type of discourse which claims to express popular interests and to represent associated identities and demands (the 'will of the people') against an 'establishment' or elite, which is seen as undermining these and forestalling their satisfaction (see also Salgado and Stavrakakis, 2018). Accordingly, populist discursive representations typically articulate a polarised antagonistic framing of the socio-political field, in a bid to inspire and mobilise frustrated/excluded social groups. The latter (named as 'the people,' the 'underdog,' 'the many,' etc.) are called to establish horizontal links (what Ernesto Laclau calls 'chains of equivalence'), which will enable them to effectively challenge the established power structure and to influence decision-making (Laclau, 2005). But how and when does populism emerge and/or succeed?

Researchers have often stressed the central role that some notion of 'crisis' plays in the manifestation of populist phenomena (Laclau, 1977: 175; Taggart, 2000: 2, 4-5, 93-94, 117; Roberts, 2015). Benjamin Moffitt has recently placed emphasis on the 
performative construction of crisis by populist discourse itself: 'if we do not have the performance of crisis, we do not have populism' (2015: 190). Connecting both perspectives, Ernesto Laclau has highlighted the dual character of social dislocation: a dislocation, the failure of an established system of representation to effectively incorporate an 'anomaly' (or 'failure') is presupposed as a triggering mechanism for new populist (and other) discursive constructions performatively narrating its characteristics and offering distinct political solutions (1990: 63, 65). In this approach, the real of the crisis (what others would call the 'objective' dimension of the crisis) becomes accessible through mediation, through its performative construction and representation by populist discourse (Stavrakakis et al., 2017).

Hence, according to an Essex School perspective, it is through the performative articulation of such narratives that 'discourses' are constituted and identities assumed. In addition, this process invariably involves 'the construction of antagonisms and the drawing of political frontiers between "insiders" and "outsiders" , (Howarth and Stavrakakis 2000: 4). In this sense, discursive articulation relies on blame attribution, on the affective investment of difference through the identification of 'constitutive outsides', thus sustaining binary oppositions such as us/them (Howarth and Stavrakakis 2000: 22). Similar conclusions can be drawn from a framing perspective. In order to render our experience meaningful, framing efforts are supposed to identify problems, diagnose causes and assign blame (Goffman, 1974; Snow and Benford 1988; Kuypers, 2010): 'framing processes also allow for the definition of the self and the opponents, in short for the definition of the "us" and the "them" category' (Caiani and Della Porta 2011: 182). 
Such a discursive and/or rhetorical perspective on framing and articulation processes alerts us to something rarely highlighted in populism research: it is never only one political force that is engaged in the aforementioned process. In fact, for every populist actor asserting its presence, there are other anti-populist actors antagonising $i t$. Hence our hypothesis is that it is not just populists who take advantage of a crisis situation in a bid to mobilise subjects and put forward a counter-hegemonic project. Hegemonic political forces and mainstream media are often the first ones to pursue a (radically anti-populist) construction of the crisis, for example, shifting the blame on to the 'populists' themselves.

In other words, it is impossible to effectively study populism without carefully examining anti-populism (Stavrakakis, 2014; Katsambekis, 2016a). And yet we rarely encounter attempts to define 'anti-populism' in ways that highlight its specificity as a type of discursive articulation and communication strategy. For example, recent studies of populist blame attribution in Greece never thematise anti-populism per se (see Gerodimos 2013; Vasilopoulou et al., 2013).

\section{Populism and Anti-Populism in Post-Authoritarian Greece (1974-2009)}

Greece's democratic history has been marked by populist mobilisations but also by periods when anti-populist actors and discourses dominated the public sphere. Indeed, it might make sense to refer to Albert Hirschman's (2002) 'shifting involvements' to better grasp the pendulum movement between periods in which populism is dominant and others in which anti-populist technocratic frames prevail. Initially, democracy was consolidated within the context of a polarised political system in which left-wing (populist/progressive) and right-wing (anti-populist/conservative) forces, represented 
by $\mathrm{PASOK}^{1}$ and New Democracy (ND) ${ }^{2}$ respectively, defended competing programmes, thus building and disseminating antagonistic collective identities (see Voulgaris, 2001). The moment of 'crisis' common to both narratives was the dictatorship era (1967-1974), which was recognised by all political forces as a major setback, if not a catastrophe.

At first, the paternalistic (but thoroughly anti-populist) figure of Konstantinos Karamanlis, a right-wing conservative politician, managed to secure for his newly established party, ND, two undisrupted terms in power (1974-1981). Karamanlis's narrative was one of stability, reconciliation and national unity on the road to EEC accession; and he managed to attract a majority of Greeks, who, after seven years of anomaly, preferred a controlled transition to democracy rather than a radical break (Pappas, 2014: 15-16). By the late 1970s, however, and throughout the 1980s, the political stage was dominated by a counter-hegemonic project: PASOK's archetypal populism and the figure of its charismatic leader, Andreas Papandreou. PASOK put forward the demands of the so-called 'non-privileged' for social justice, popular sovereignty and national independence, against an 'establishment' accused of monopolising political access and economic privilege in various ways since the end of the Greek Civil War (1946-1949).

\footnotetext{
${ }^{1}$ PASOK (Panhellenic Socialist Movement) was founded by Andreas Papandreou in 1974. Emerging initially as a radical-left political force, it adopted a more moderate profile in the 1980s, to gradually join the trajectory of third-way European social-democracy from the mid-1990s onwards. It was one of the main pillars of the Greek two-party system but its popular support deteriorated after its implementation of the first wave of austerity (2009-2012).

${ }^{2}$ Founded in 1974 by Konstantinos Karamanlis, ND is a centre-right conservative party and one of the pillars of the Greek two-party system.
} 
Perhaps inspired by Peron's identification with the descamisados ('the shirtless'), Papandreou in the 1970s communicated his anti-systemic bid to represent the nonprivileged by avoiding wearing ties, preferring his landmark turtleneck sweater. It was through such enactments of the politically incorrect and by articulating publicly the previously unsayable (for example, attacking local elites and global powers like the US) that Papandreou managed to performatively cultivate his populist charisma. ${ }^{3}$ PASOK's populist rhetoric gained massive popular support, resulting in a remarkable 48.07 per cent of the vote in the 1981 election (Spourdalakis, 1988).

In 1989, PASOK faced defeat, following a massive scandal that allegedly involved its leader. Greece itself entered a period of turbulence, holding three consecutive elections within less than a year, until a government (that of Konstantinos Mitsotakis and ND) could enjoy a fragile majority in parliament. Interestingly, Mitsotakis's government (1990-1993) was probably the first one to be directly registered as 'antipopulist', since it chose to attack PASOK and its leader with reference to their populism, demagoguery, irresponsibility, etc. (Vernardakis, 2011: 3; Voulgaris, 2001: 321), while trying to implement a programme based on labour- and marketderegulation, privatisation and restrictive fiscal policies.

Coping with the reasons for its defeat and internal crisis, PASOK gradually developed a similar anti-populist narrative, which attributed the blame for the party's - as well as for Greece's - problems to 'populism'. This movement from populism to antipopulism had its roots in the interventions of Costas Simitis, a minister in Andreas Papandreou's administrations who would later become president of PASOK and

\footnotetext{
${ }^{3}$ For a discursive, performative theory of charisma, see Scott, 1990; Stavrakakis, 2015.
} 
prime minister. Simitis had argued, from the 1980s, that PASOK should become a 'force of modernisation', adopting an emphatically anti-populist identity and strategy (Pantazopoulos, 2011). In a sense, Mitsotakis and Simitis can be regarded as key actors involved in the anti-populist swing of the pendulum away from populist rhetoric during the 1990s.

Soon, confrontations on the left/right axis gave way to a discourse of consensus accompanied by the constant denunciation of populism, which was a way for the PASOK of Simitis to renounce the party's 'egalitarian' past. On the centre-right, ND followed the 'moderation' trend, electing a new centrist and consensus-oriented leader, Costas Karamanlis (nephew of Konstantinos), who also named 'populism' as one of his main enemies, identifying it with PASOK and its legacy in government; he launched a new communication strategy of Clinton-inspired 'triangulation' in the late 1990s (Katsambekis, 2016a).

Despite the privileging of consensus by traditional political parties, the socio-political field started to become more contentious after 2008. If the trauma of the 1967-1974 dictatorship and the post-civil-war regime triggered a gradual polarisation along the populism/anti-populism axis and a delayed populist hegemony, the turn of events put in motion by the recent economic crisis had even more profound effects on the political system, leading to a speedy reactivation of the populism/anti-populism divide and a consolidation of a (precarious) populist hegemony within just a few years.

\section{Enter Crisis: Reactivating the Populism/Anti-Populism Divide}

The eventual breakdown of 2010 shook previously existing alliances, collective identities, loyalties and social compromises, initiating a radical dislocation of Greek 
society and politics. The trends of public discourse shifted violently from individualist cynicism to 'punitive asceticism': 'we lived beyond our means', 'the party is over', 'we all "ate" the money together', were characteristic mottos of a dominant political and media discourse that was used to spread feelings of collective blame and guilt (Stavrakakis, 2016; 2013). The 'irresponsible populism' of the past decades that 'flattered the people' with false promises was identified as the root of Greece's collective pathology (Sevastakis and Stavrakakis, 2012). In this sense, anti-populist representations of the crisis were already playing a key role in mediating blame attribution even before the emergence of popular resistances to austerity. Antipopulist narratives were actually dominant in the public sphere, articulated both by mainstream media and traditional political forces; they were only challenged after the emergence of the aganaktismenoi ('indignant') movement in May 2011 and (even more so) after the elections of May-June 2012, which resulted in a major political realignment.

PASOK, under the leadership of George Papandreou (son of Andreas), having returned to power, was the party that struggled with the administration of the crisis in its first phase. The optimistic narrative (promising fairer taxation, participatory democracy and 'green growth') that brought it to power in October 2009 stigmatised as 'populist' by ND - had to be abandoned within a few months, as Greece faced severe difficulties due to its massive deficit and inability to sustain debt repayments. With the country standing on the verge of bankruptcy, an ad hoc mechanism was put together by the EU and the IMF, offering emergency loans under the condition that a programme of structural reforms and harsh austerity was implemented (Pappas, 2014). 
After the implementation of the first wave of austerity, Greek society entered a period of significant turbulence as GDP contracted, unemployment soared and salaries, along with pensions, were severely cut. The months that followed witnessed various forms of massive collective action against the government. The most salient movement of that period was that of the so-called aganaktismenoi which followed the demonstrations of the Indignados and the 15-M movement in Spain in May 2011 (Kioupkiolis and Seoane Pérez, 2018). A grassroots populist movement claiming to represent the will of 'the people' against an alienated and unresponsive 'establishment' (Prentoulis and Thomassen, 2014), this was probably the first serious challenge to the anti-populist discourse of the Greek government and mainstream media, coming from 'below'.

With social tensions on the rise, George Papandreou was soon forced to resign and PASOK, with ND and smaller parties (initially, the extreme-right LAOS and later on the moderate-left DIMAR), formed a series of coalition governments. Thus Greece's traditional parties co-governed for the first time, sharing a very similar rhetoric, which denounced any opposition to the implementation of the 'bail-out' programme as 'populism'. It is from this moment (the formation of the Papademos government in November 2011) onwards that the division between alleged 'populist' and 'antipopulist' political parties coincided with that between 'moderate' (or mainstream) forces and those that acted as 'challengers'. Things were much more complicated up to that point. Antonis Samaras's ND - the centre-right 'pillar' of the party system exhibited strong nationalist (and some populist) characteristics between the election of 2009 and its collaboration with PASOK in 2011. In that period, ND castigated PASOK's policies regarding the administration of the crisis - especially its decision 
to sign the so-called 'memorandum' (the written agreement between Greece and its lenders regarding the first bailout package, signed on May 2010) - and tried to articulate an alternative (see Gemenis and Nezi, 2015; Vasilopoulou et al., 2013). It is crucial to stress, however, that ND's opposition to PASOK up until their collaboration was mostly based on moralistic arguments, stressing that 'the memorandum was unnecessarily humiliating' for the Greek nation (Gemenis and Nezi, 2015: 22). This is another indication that, despite its salience and persistence, the populism/antipopulism divide is not static: it is quite dynamic and malleable, in fact, with political forces having historically occupied positions at both sides of the spectrum.

Against the anti-populist discourse of mainstream parties and media, a previously marginal radical-left formation started to gain momentum. The Coalition of the Radical Left (SYRIZA) addressed 'the people' through a discourse that articulated various popular demands and grievances against the Greek and European 'elites' and their policies of austerity along the lines of an 'us' versus 'them' schema (Stavrakakis and Katsambekis, 2014). SYRIZA's rise to prominence established a new, sharp polarisation within the Greek political system: pro-austerity/pro-memorandum political forces (mainly represented by PASOK and ND) against anti-austerity/antimemorandum forces (mainly represented by SYRIZA). Along with SYRIZA, Independent Greeks (ANEL), a new political party that emerged from a split in ND in 2012, would enter parliament, expressing right-wing and nationalist populist sentiments and gradually creating links with SYRIZA, leading to the collaboration of the two parties in government after January 2015. Not surprisingly, 'opponents and critics of the SYRIZA-ANEL coalition' framed their opposition to the government 'predominantly as a noble battle against populism' (Aslanidis and Kaltwasser, 2016: 
5). Thus, cutting across ideological-political persuasions, the opposition between populism and anti-populism would coincide from January 2015 onwards with that between government (populists) and opposition (anti-populists), while during the previous period it had been exactly the opposite.

\section{Populist and Anti-Populist Actors in a Period of Realignment (2012-2016)}

In order to understand the dynamic of SYRIZA and relate it to the emerging populism/anti-populism cleavage, we need to take into account the inability of traditional parties to offer a convincing narrative able to address the post-2010 systemic dislocation and its spillover into a crisis of political representation. Their favoured communication strategy - to blame both 'populism' for the crisis as the main symptom of the malaise of the post-authoritarian era as well as 'the people' themselves as the irresponsible beneficiaries of a democratisation process that went too far - eventually failed to contain popular reaction; instead, it fuelled indignation. On the other side, SYRIZA engaged with the demands of the anti-austerity movement, trying to represent impoverished and disenfranchised social groups in its discourse, constructing and performing, in this way, its own version of the 'crisis', attributing the blame to the 'old' 'two-party establishment' (PASOK/ND) and to the neoliberal policies imposed by the EU and the IMF (Stavrakakis and Katsambekis, 2014; Katsambekis, 2016b). In terms of style and communication strategy, reactivating Andreas Panadreou's tactic, Alexis Tsipras, SYRIZA's leader, likewise refrained from wearing ties and engaged in the public articulation of the previously unsayable, both at the local and international level - with a lot of help from an outspoken Yanis Varoufakis (Stavrakakis, 2015). An example here is Varoufakis' now infamous joint press conference with Jeroen Dijsselbloem in which the former characterized the 
'troika' as 'a rottenly constructed committee' with which Greece would no longer cooperate (Hope and Wagstyl 2015). Another example comes again from Varoufakis, who described austerity as 'fiscal waterboarding' (Hüetlin and Neubacher 2015), while we could also add Tsipras' sharp public critique of the EU's democratic deficit and the lack of accountability of institutions like the Eurogroup, along with his statements that the SYRIZA-led government prioritises paying pensions and salaries to servicing its debt obligations to the IMF (Spiegel 2015).

The increasing hegemonic potential of SYRIZA further reinforced the anti-populism of the established party and media systems: a quasi-apocalyptic discourse, marked by a strong anti-populist emphasis, was thus articulated, a discourse that intensified even further after 2012, when SYRIZA achieved second place in the national elections. In this context, demonisation, blame attribution and fearmongering seemed to have taken the place of political confrontation based on exchange of arguments, in an antagonistic schema that left very little room for compromise and created the conditions for a climate of 'blind polarisation' (Katsambekis, 2016a, 2016b) to emerge.

Contemporary research has offered ample evidence to support this account of the reactivation and consolidation of a populism/anti-populism frontier (Stavrakakis et al., 2016, 2017). For example, within the POPULISMUS research project, we have participated in the construction of a populism index utilised in the Greek Candidate Study of 2015 (part of the joint multi-national project Comparative Candidate Survey/CCS). Taking into account a series of studies on populist attitudes (e.g. Akkerman et al., 2014; Hawkins et al., 2012), this index was based on a reformulated battery of eight (five-point Likert) items. Six of those items were drawn from the 
battery proposed to CSES, one item (the one concerning the moral dimension) was excluded, and two additional items were added. In this context, our index measures populist attitudes based on a battery that is in line with a discursive approach to populism based on 'minimal criteria' (Stavrakakis et al., 2016: 8-9; see also Stavrakakis and Katsambekis 2014). On the basis of 520 questionnaires completed between February and July 2015 (after the election of January 2015), it has become possible to distinguish two distinct (and indeed antagonistic) party groups along the populism/anti-populism axis: on the one side we find ANEL and SYRIZA (partners in government since January 2015); on the other PASOK and ND (partners in government from late 2011 and throughout 2014), along with the centrist-liberal RIVER $^{4}$ (see Figure 1; for more details of our methodology see Stavrakakis et al., 2016).

FIGURE 1 HERE

\footnotetext{
${ }^{4}$ The Communist Party of Greece (KKE) and Golden Dawn (GD) have always and consistently refused to provide a list of email addresses for their candidates. They were thus not included in the survey (see Stavrakakis et al. 2016: 8-9).
} 
Figure 1: Populism Index by political party.

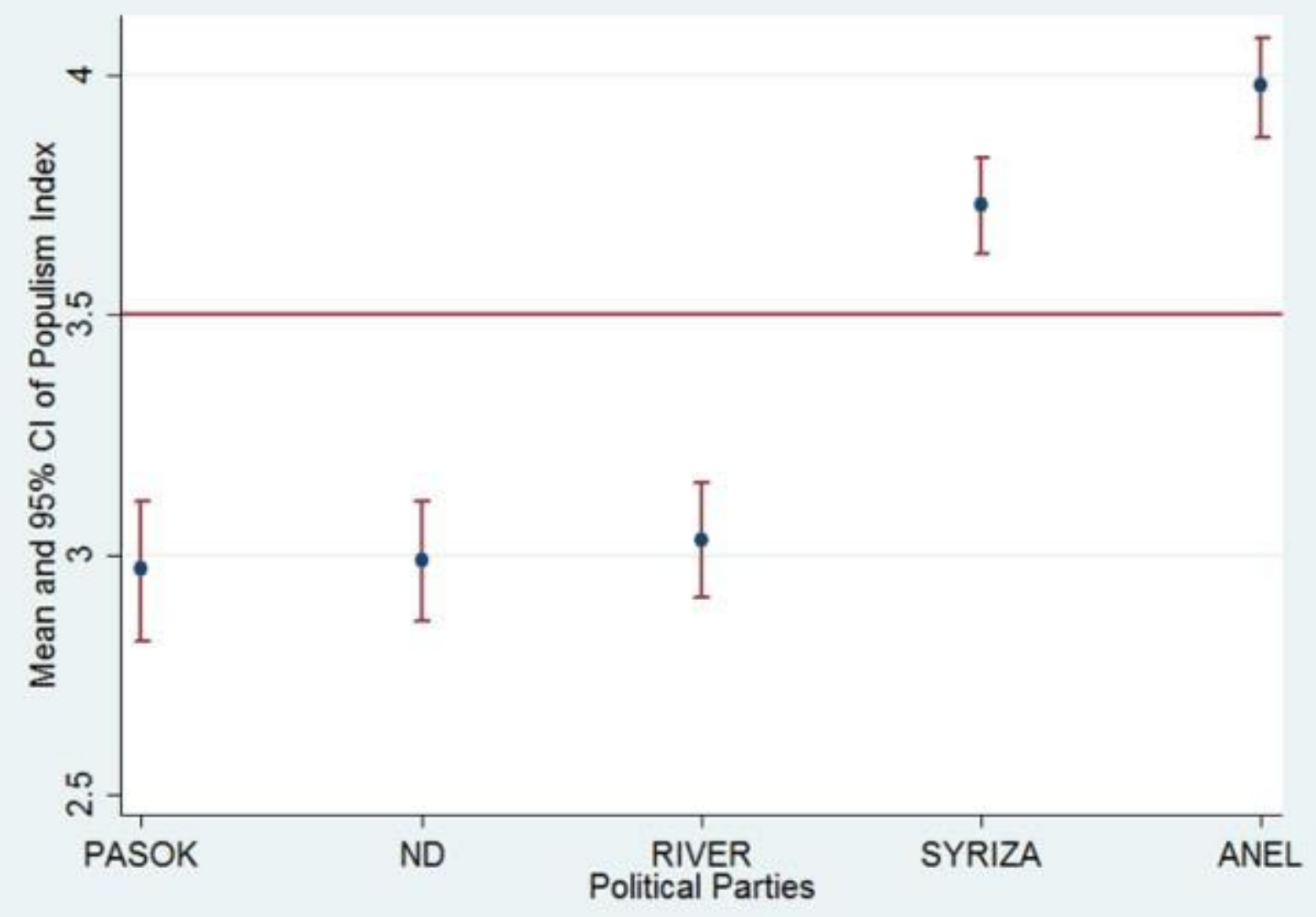

Source: Stavrakakis et al. 2016: 11.

Moreover, in an effort to corroborate the existence of a similar divide in the media, we surveyed a series of corpora constructed on the basis of a total of 17,363 articles to which we had access, published in the Greek printed press between 1 June 2014 and 31 May 2015 (for a detailed analysis, see Nikisianis et al., 2016). After qualitative assessment, 928 among these articles from forty newspapers and magazines were considered relevant (based on references to 'populism,' 'the people' and 'popular sovereignty/will') and were subsequently coded. A maximum effort was made to include, with proportional representation, all the views that have been identified 
(following the logic of qualitative stratified sampling). Those articles were categorised according to four main criteria:

1. Positive stance towards populism and/or 'the people,' 'popular sovereignty', etc. (those articles are not necessarily populist, but express what can be termed as 'populist friendly' views).

2. Clear anti-populist positioning.

3. Neutral stance towardspopulism.

4. No reference to populism but rather to other notions, such as 'democracy', 'crisis', etc.

What emerged from this analysis was, once more, a clear division between ostensibly 'anti-populist' and 'pro-populist' media and articles (see Table 1). Moreover, this study established the polarisation implicit in pro-populist discourse, but also the demonisation of 'populism' (and the political forces denounced as populist, mainly SYRIZA) by the anti-populist press (where populism is often metaphorically described as a plague, gangrene, cancer, madness, schizophrenia, etc.).

Two main observations follow: (1) the populism/anti-populism divide is clearly reflected in the Greek press; (2) the anti-populist press, which is clearly dominant in quantitative terms (see Table 1; see also Nikisianis et al., 2016: 56), very often uses profoundly bellicose and dismissive language against alleged 'populists', characterising them as threatening, pathogenic or parasitic entities that should be eradicated. This means that it is not only populist actors that privilege antagonistic/polarising confrontation in the public sphere, but also - and sometimes even more strongly - self-proclaimed 'anti-populist' actors, aiming to establish their own divisions and polarities. 
TABLE 1 HERE

Table 1. Coding of pro-populist and anti-populist articles in the Greek Press (June 2014 - May 2015)

\begin{tabular}{|l|l|l|}
\hline Coding & Articles & Percentage \% \\
\hline Pro-populist & 213 & 23.20 \\
\hline Anti-populist & 489 & 53.27 \\
\hline Neutral & 23 & 2.51 \\
\hline No references & 193 & 21.02 \\
\hline Total & $\mathbf{9 1 8}$ & $\mathbf{1 0 0 . 0 0}$ \\
\hline
\end{tabular}

Source: Nikisianis et al., 2016: 56

After SYRIZA came to power in January 2015, Greece entered a new period of turbulence. When negotiations with the country's European partners reached a deadlock, Tsipras called for a referendum on the 'bail-out' terms proposed to Greece. The citizens rejected the proposed deal by a majority of 61.31 per cent. The days preceding the referendum were revealing about the depth the populism/anti-populism frontier had acquired on a variety of levels. As noted by Paris Aslanidis and Cristóbal Rovira Kaltwasser, it rallied 'the sum of the media establishment behind an openly pro-YES, pro-European campaign, applying immense pressure on the government and subsequently confirming the anti-establishment credentials of the populist government in the eyes of many' (Aslanidis and Kaltwasser, 2016: 9).

Yet SYRIZA soon had to retreat and accept a new bail-out agreement. As a result, its populist discourse has gradually toned down, although it has not vanished 
(Katsambekis 2017). But the anti-populist opposition's discourse seems to have become even more bellicose and polarising. We might have expected to see this narrative disappear or at least become milder in tone after SYRIZA had started to implement a programme that was agreed with Greece's European partners and the situation started to stabilise somewhat. On the contrary, the anti-populist narrative fuelled by mainstream media and traditional/mainstream parties intensified. In fact, it became the cornerstone of the official campaign of the main opposition party, ND, which now declared as its ultimate aim to defeat the populism incarnated in SYRIZA, constantly urging Tsipras to resign (Samaras, 2016; Mitsotakis, 2016a; Mitsotakis, 2016b). Interestingly, Kyriakos Mitsotakis's (son of Konstantinos and leader of ND since January 2016) social media slogan ('Leave!,' hashtag \#fygete), introduced in spring 2016, closely resembles the one that SYRIZA used back in 2012 against the coalition government of ND, PASOK and DIMAR. ${ }^{5}$

In a similar manner, mainstream media, like the newspapers To Vima (centre-left) and Kathimerini (centre-right), continue to attack the SYRIZA-led government as a serious threat to the country's development and to its democratic institutions with reference to its alleged populism, comparing Tsipras to Venezuela's Nicolás Maduro and other populist leaders from around the world. Some commentators and journalists even suggest that Tsipras wishes to establish a new 'regime' in Greece (the 'SYRIZA regime'), based on clientelism and the illiberal manipulation of institutions (mainly

\footnotetext{
5 'Greece cannot bear you anymore Mr Tsipras. Leave.' read the motto of Mitsotakis's Twitter campaign, initiated in March 2016, while SYRIZA's slogan in 2012 was 'You are destroying the country. Leave now.' See https://twitter.com/kmitsotakis/status/714880661719486466;
} https://left.gr/news/i-sygklonistiki-paroysia-ton-voyleyton-toy-syriza-ekm-sti-sygkentrosi-toy-laoyvinteo. 
the media and the judiciary), ${ }^{6}$ and which would enable the (populist) left to stay in power permanently (Papadopoulos 2016; Kroustali 2016). Within this narrative, commentators in mainstream newspapers rarely miss the chance to equate the populism of the left with that of the right: 'Right-wing populism is similar to left-wing [populism]. The only thing that changes are the symbols, the flags and banners at the demonstrations of the outraged popular masses ...' (Coutifaris 2017). What is more, by equating the radical left with the extreme right, anti-populist commentators can easily reaffirm the populism/anti-populism divide, equating populism with the irrational and uneducated masses and anti-populism with rational meritocracy:

The political convergence of the postmodern Left with the lunatic Right illustrates the power of populism against rationalism in our days. The postmodern leftist perception converges with that of the Right in the hate of the 'little man', either right-wing or left-wing, against the educated and the aristoi ... (Veremis 2017).

Our observations here confirm the findings of recent studies that stress anti-populism as one of the main characteristics of mainstream media in Greece (see Lialiouti and Bithymitris, 2013; Mylonas 2014), while it is also crucial to note the often deeply moralistic character of anti-populist discourse. Needless to say, such pronounced antipopulism is not a peculiar characteristic of the Greek case; in Portugal, for example, it still seems to condition the overall positioning of the country's party system and media, preventing the establishment of significant populist actors in the crisis setting,

\footnotetext{
${ }^{6}$ Such accusations have intensified following the failure of an attempt by the government to regulate the media field (issuing a limited number of television licences) and disagreements with the judiciary on many court decisions affecting its media law and taxation policies.
} 
but - crucially - allowing the hegemonic emergence of non-populist alternatives (Salgado, 2018).

\section{Conclusion}

In this article, we have attempted to shed light on crucial aspects of the antagonistic dialectic between populist and anti-populist discourses in the Greek context.

Presenting a diachronic reading of this antagonistic relationship, we have argued that the populism/anti-populism antithesis may be understood as a salient discursive divide, which becomes 'reactivated' and indeed dominant in conditions of 'failure' or 'dislocation,' like those brought about by the recent economic crisis.

Highlighting this persistent antagonistic relationship is a response to arguments that consider Greece a populist democracy (Pappas, 2014: 36). In our genealogy, Greece's political system is a terrain on which populist and anti-populist actors construct rival hegemonic projects; at times, the one or the other (temporarily) prevails, while periodic crises can reactivate and further intensify associated polarities. In this sense, looking back at the previous decades of Greece's democratic history, although it is true that most governing and main opposition parties have indeed used confrontational and simplistic discourses, it is very difficult to find a period in which both such parties could be simultaneously regarded as populist.

What also emerges from our analysis is that often it is anti-populist discourses that purport to pre-empt popular mobilisations, by denouncing any opposition as 'populist'. Indeed, it is only against the dominance of the anti-populist camp in the country's public discourse from the mid-1990s onwards that the recent electoral success of the populist radical left (SYRIZA) can be registered as a (populist) anomaly. This anti- 
populist orientation has been reflected in recent surveys of the Greek press, contradicting accounts that consider that populism is dominant Greece's public discourse (Pappas 2014; Vamvakas, 2015).

What is more, the polarisation patterns observed seem to acquire an autonomous dynamic, independent from the policies implemented. Hence, even after SYRIZA's capitulation in July 2015, the populism/anti-populism divide continues to dominate Greek politics, media and academic discourse, constantly constructing polarities with reference to various policy issues (from referendums to constitutional review and from the electoral law to education reform).

Last but not least, what emerges as a crucial issue in the preceding analysis is the very nature of the populism/anti-populism divide. For example, does it constitute a proper cleavage? Following Vít Hloušek (2010), on the basis of the Greek example we can maintain that it is in discourse that cleavages are (partially) constructed, represented and enacted. Thus, if a 'divide' designates a sharp discursive opposition privileged within a given conjuncture, then a divide which has become salient and hegemonic in public discourse throughout a significant period may be designated as a 'cleavage'.

To the extent that we can observe such a salience in the populism/anti-populism divide throughout Greece's democratic history, and given that it has consistently acquired a key position in signifying political stakes and antagonisms, manifesting on the discursive, the attitudinal (see candidate survey) and the press/media levels (see press analysis), operating along or even penetrating more traditional cleavages (e.g. left/right), one might feel inclined to suggest that the populism/anti-populism discursive frontier may be understood as an emerging cleavage. Building on the salience of a high/low divide in many contexts, Pierre Ostiguy has indeed correlated it 
with the antagonism between populism and anti-populism, elevating it into a proper cleavage (2009: 23-24). The preceding analysis of populist and anti-populist representations in the Greek context seems to confirm the salience of such a high/low, populism/anti-populism antagonism in the Greek context, offering thus new evidence in support of such a discursive-performative theorisation of cleavages.

This orientation should not be confused with the aforementioned 'populist democracy' argument. This thesis sees Greek political culture as divided by only 'one single cleavage ostensibly separating "the people" from a host of political and economic elites, whether domestic (such as the old parties, but also young ones like Potami) or foreign (such as the Troika)' (Pappas, 2015; see also Vasilopoulou et al., 2013). And yet, this thesis seems to suffer from two weaknesses:

1) Even if one is prepared to accept the populism/anti-populism divide as an emerging cleavage, to argue that it constitutes the only one within the Greek context crucially ignores the fact that, in a variety of important issues, both populist and anti-populist forces have voted in line with their left/right affiliation. For example, on same-sex civil unions, the creation of a mosque in Athens and the naturalisation of immigrant children, SYRIZA and ANEL, the two populist coalition partners, have voted in opposing ways in line with a left/right cleavage or a GAL/TAN division (Stavrakakis et al., 2016).

2) Most crucially, however, what type of cleavage can that be in which all sides involved espouse the same articulatory/framing strategy and fall under the same category (populism)? This paradoxical conclusion, which goes against the genealogy we have presented, can only be sustained at the expense of a rigorous definition of populism and of the complex choreography between populism and anti-populism. For 
example, it often relies on an equation between populism and clientelism

(Vasilopoulou et al., 2013: 13), which has been long ago discredited by Nicos

Mouzelis (1986). It is only on the basis of such misunderstandings that the cleavage between populism and anti-populism, bottom-up and top-down incorporation, low and high, can be camouflaged as an intra-populist division and Greek political culture as a whole can be designated as 'populist' in toto.

\section{Acknowledgements}

This article draws on the conclusions of the POPULISMUS research project (www.populismus.gr), which was undertaken at the Aristotle University of Thessaloniki (2014-2015), with funding from the European Union (European Social Fund) and National Funds (Greece) within the framework of the Operational Programme 'Education and Lifelong Learning' (Action 'ARISTEIA II'). Giorgos Katsambekis wishes to thank the Research Committee of the Aristotle University of Thessaloniki (https://www.rc.auth.gr/) for its generous support through the 'Excellence Scholarship' for postdoctoral researchers (2016).

\section{References}

Akkerman A., Mudde C. and Zaslove A. (2013) 'How populist are the people? Measuring populist attitudes in voters', Comparative Political Studies 47(9): 1324-1353. 
Aslanidis, P., and Rovira Kaltwasser, C. (2016) 'Dealing with populists in government: the SYRIZA-ANEL coalition in Greece', Democratization, DOI: 10.1080/13510347.2016.1154842.

Caiani, M., and Della Porta, D. (2011) 'The elitist populism of the extreme right', Acta Politica 46(2): 180-202.

Coutifaris, K.V. (2017) 'Populism, the apolitical dogma that is based on lies', Ekathimerini.com, March 30, available at www.kathimerini.gr/902952/opinion/epikairothta/politikh/laikismos-apolitikodogma-poy-sthrizetai-sto-yema, accessed October 20, 2017.*

Diamandouros, N. (1994) Cultural Dualism and Political Change in Postauthoritarian Greece, Madrid: Instituto Juan March de Estudios e Investigaciones.

Gemenis, K., and Nezi, R. (2015) 'Government-opposition dynamics during the economic crisis in Greece', Journal of Legislative Studies 21(1): 14-34.

Gerodimos, R. (2013) 'The ideology of far left populism in Greece', Political Studies, DOI: $10.1111 / 1467-9248.12079$.

Goffman, E. (1974) Frame Analysis: An Essay on the Organization of Experience, New York: Harper \& Row.

Hawkins K. A., Riding S., and Mudde, C. (2012) 'Measuring populist attitudes', Political Concepts Committee on Concepts and Methods Working Paper Series, 55 . 
Hirschman, A. O. (2002) Shifting Involvements, Princeton, NJ: Princeton University Press.

Hope, K. and Wagstyl, S. (2015) 'Greece will no longer deal with "troika”, Yanis Varoufakis says,' Ft.com, January 30, https://www.ft.com/content/2403f3e8a8a4-11e4-97b7-00144feab7de, accessed October 20, 2017.

Howarth, D. and Stavrakakis, Y. (2000) 'Introducing discourse theory and political analysis', in D. Howarth, A. Norval and Y. Stavrakakis (eds) Discourse Theory and Political Analysis, Manchester: Manchester University Press.

Hloušek, V. (2010) 'European integration as a party cleavage? A conceptual debate', available at http://cepsa.at/ablage/2011/paper_hlousek.pdf, accessed October $20,2017$.

Hüetlin, T. and Neubacher, A. (2015) 'Greek Finance Minister Varoufakis: “Austerity Has Done Nothing to Solve Greece's Problems”, Spiegel online, February 16, 2015, www.spiegel.de/international/europe/interview-with-greek-financeminister-giannis-varoufakis-a-1018443.html, accessed October 20, 2017.

Katsambekis, G. (2016a) “"The people” and political opposition in post-democracy’, in J. Cook, N. J. Long and H. L. Moore (eds) The State We're In: Reflecting on Democracy's Troubles, Oxford: Berghahn Books, pp.144-166.

Katsambekis, G. (2016b) 'Radical left populism in contemporary Greece', Constellations 23(3): 391-403.

Katsambekis, G. (2017) 'The ambiguities of SYRIZA's populism in power', kultuRRevolution 72: 22-26. 
Kioupkiolis, A., and Seoane Pérez, F. (2018) 'Reflexive technopopulism: Podemos and the search for a new left-wing hegemony', in S. Salgado and Y. Stavrakakis (eds) Populist Discourses and Political Communication in Southern Europe, symposium, European Political Science, DOI: .

Kroustali, D. (2016) 'How are they building the SYRIZA regime', Tovima.gr, March 6, available at http://www.tovima.gr/politics/article/?aid=782263, accessed October 20, 2017.*

Kuypers, J. (2010) 'Framing analysis as a rhetorical process', in P. D'Angelo and J. Kuypers (eds) Doing News Framing Analysis: Empirical and Theoretical Perspectives, New York: Routledge, 286-311.

Laclau, E. (2005) On Populist Reason, London: Verso.

Lialiouti, Z., and Bithymitris, G. (2013) 'Crisis, hegemony and the media. The case of SKAI / Kathimerini', Greek Political Science Review 40: 139-173.

Lyrintzis, C. (2005) 'The changing party system: stable democracy, contested “modernisation" ', West European Politics 28(2): 242-259.

Mitsotakis, K. (2016a) 'Statement of the newly elected president of New Democracy', New Democracy, January 11, available at http://nd.gr/nea/dilosi-toy-

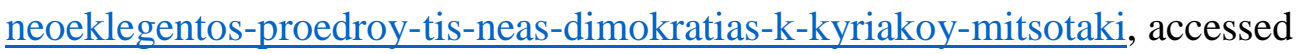
October 20, 2017.*

Mitsotakis, K. (2016b) 'Mitsotakis slams populism, vows to fight electoral change', Ekathimerini.com, June 29, available at 
www.ekathimerini.com/210006/article/ekathimerini/news/mitsotakis-slamspopulism-vows-to-fight-electoral-change, accessed October 20, 2017.

Mouzelis, N. (1986) Politics in the Semi-Periphery, London: Macmillan.

Mudde, C., and Kaltwasser, C. Rovira (2017) Populism: A Very Short Introduction, Oxford: Oxford University Press.

Mylonas, Y. (2014) 'Crisis, austerity and opposition in mainstream media discourses of Greece', Critical Discourse Studies 11(3): 305-321.

Nikisianis, N., Siomos, T., Stavrakakis, Y., and Dimitroulia, T. (2016) 'Populism vs. anti-populism in the Greek press, 2014-2015', Synchrona Themata 132-3: $52-70{ }^{*}$

Pappas, T. (2014) Populism and Crisis Politics in Greece, Basingstoke: Palgrave Macmillan.

Pappas, T. (2015) 'Populist hegemony in Greece', Open Democracy, 25 September, available at www.opendemocracy.net/can-europe-make-it/takis-s-pappas/populisthegemony-in-greece, accessed October 20, 2017.

Pantazopoulos, A. (2011) Populism and Modernization, Athens: Estia.*

Papadopoulos, P. (2016) 'Alexis Tsipras: the "little guy" that wants to become an emperor', Tovima.gr, June 26, available at http://www.tovima.gr/politics/article/?aid=810626, accessed October 20, 2017.* 
Roberts, K. (2015) 'Populism, political mobilizations, and crises of political representation', in C. de la Torre (ed.) The Promise and Perils of Populism, Lexington, KY: University Press of Kentucky, 140-158.

Salgado, S., and Stavrakakis, Y. (2018) 'Introduction: populist discourses and political communication in Southern Europe', in S. Salgado and Y. Stavrakakis (eds) Populist Discourses and Political Communication in Southern Europe, symposium, European Political Science, DOI: .

Salgado, S. (2018) 'Where's populism? Online media and the diffusion of populist discourses and styles in Portugal', in S. Salgado and Y. Stavrakakis (eds) Populist Discourses and Political Communication in Southern Europe, symposium, European Political Science, DOI: .

Samaras, A. (2016) 'Samaras: ND united to win the battle against populism', Ekathimerini.com, January 11, available at http://www.kathimerini.gr/845238/article/epikairothta/politikh/samaras-h-ndenwmenh-na-kerdisei-th-maxh-kata-toy-laikismoy, accessed October 20, $\underline{2017 . *}$

Scott, J. (1990) Domination and the Arts of Resistance, New Haven, CT: Yale University Press.

Sevastakis, N., and Stavrakakis, Y. (2012), Populism, Antipopulism and the Crisis, Athens: Nefeli.*

Snow, D. A., and Benford, R. D. (1988) 'Ideology, frame resonance, and participant mobilization', International Social Movement Research 1: 197-217. 
Spiegel, P. (2015) 'Greece's leader warns Merkel of “impossible” debt payments', Ft.com, March 23, 2015, https://www.ft.com/content/ae9d0cb8-d0b5-11e4$982 a-$

00144feab7de?ftcamp=published_links $\% 2$ Frss $\% 2 F b r u s s e l s \% 2 F f e e d \% 2 F \% 2 F$ product\#axzz3V70Sdj6A, accessed October 20, 2017.

Spourdalakis, M. (1988) The Rise of the Greek Socialist Party, London: Routledge.

Stavrakakis, Y. (2013) 'Dispatches from the Greek lab: metaphors, strategies and debt in the European crisis', Psychoanalysis, Culture \& Society 18(3): 313-324.

Stavrakakis, Y. (2014) 'The return of "the people:" populism and anti-populism in the shadow of the European crisis', Constellations 21(4): 505-517.

Stavrakakis, Y. (2015) 'Populism in power: SYRIZA's challenge to Europe', Juncture 21(4), 273-280.

Stavrakakis, Y. (2016) 'Debt society consolidated? Post-democratic subjectivity and its discontents', in J. Cook, N. J. Long and H. L. Moore (eds) The State We're In: Reflecting on Democracy's Troubles, Oxford: Berghahn Books.

Stavrakakis, Y., and Katsambekis, G. (2014) 'Left-wing populism in the European periphery: the case of SYRIZA', Journal of Political Ideologies 19(2): 119142.

Stavrakakis, Y., Andreadis, I. and Katsambekis, G. (2016) 'A new populism index at work: identifying populist candidates and parties in the contemporary Greek context', European Politics and Society, DOI:

$10.1080 / 23745118.2016 .1261434$ 
Stavrakakis, Y., Katsambekis, G., Kioupkiolis, A., Nikisianis, N., and Siomos, T. (2017) 'Populism, anti-populism and crisis', Contemporary Political Theory, DOI: $10.1057 / \mathrm{s} 41296-017-0142-y$.

Vasilopoulou, S., Halikiopoulou, D., and Exadaktylos, Th. (2013) 'Greece in crisis: austerity, populism and the politics of blame', Journal of Common Market Studies, DOI: 10.1111/jcms.12093.

Veremis, T. (2017) 'Eleftherios Venizelos and populism’, Ekathimerini.com, February 19, available at http://www.kathimerini.gr/896977/opinion/epikairothta/politikh/eley8eriosvenizelos-kai-laikismos, accessed http://www.kathimerini.gr/845238/article/epikairothta/politikh/samaras-h-ndenwmenh-na-kerdisei-th-maxh-kata-toy-laikismoy.*

Vernardakis, C. (2011) Political Parties, Elections and Party Systems, Athens: Sakoulas.*

Voulgaris, Y. (2001) The Greece of Metapolitefsi 1974-1990, Athens: Themelio.* *In Greek

Yannis Stavrakakis is Professor of Political Discourse Analysis at the Aristotle University of Thessaloniki, Greece, where he directs the POPULISMUS Observatory of populist discourse: www.populismus.gr.

Giorgos Katsambekis has worked at the Aristotle University of Thessaloniki as a postdoctoral researcher and an adjunct lecturer. In November 2017 he is joining 
Published in European Political Science, First Online: 22 January 2018, DOI:

https://doi.org/10.1057/s41304-017-0138-3

Loughborough University as a Lecturer in European and International Politics. He is also a member of the POPULISMUS research team: www.populismus.gr. 